\title{
PENINGKATAN PERILAKU SEKS SEHAT MELALUI MODEL TERAPI KELOMPOK PADA PEKERJA SEKS KOMERSIAL
}

\author{
Loetfia Dwi Rahariyani $^{* *}$, Yohanes Kambaru Windi ${ }^{1}$, Nikmatul Fadilah $^{1}$, Kuntoro $^{2}$ \\ 1. Program Studi Keperawatan Sutopo Poltekkes Kemenkes Surabaya, Jawa Timur 55555, Indonesia \\ 2. Fakultas Kesehatan Masyarakat Universitas Airlangga Surabaya, Jawa Timur , Indonesia \\ *Email: rahariyani@yahoo.com
}

\begin{abstract}
Abstrak
Keberhasilan pencegahan penularan penyakit menular seksual (PMS) tidak hanya tergantung pada pemerintah/tenaga kesehatan dan lembaga swadaya masyarakat (LSM) yang peduli dengan kasus ini saja, tetapi partisipasi aktif dari kelompok yang mempunyai resiko tinggi tertular (Pekerja Seks Komersial) sangat memegang peran penting. Oleh karena itu mengikut sertakan kelompok resiko tinggi dalam kegiatan pencegahan PSM perlu dilakukan. Tujuan penelitian ini adalah untuk mengetahui efektifitas model terapi kelompok (intensive problem solving group) dalam meningkatkan perilaku seks yang sehat. Desain penelitian ini adalah Pra Eksperimental, jenis pretest-postest design. Sampel penelitian sebanyak 20 orang PSK yang terbagi menjadi dua group, masing masing group terdiri dari 10 orang. Setiap group mendapat intervensi tiga kali terapi kelompok pada subyek yang sama. Setelah dilakukan penelitian dan dianalisis dengan menggunakan uji statistik paired $\mathrm{t}$ - test, hipotesis penelitian diterima ada perbedaan pengetahuan, sikap dan prilaku sebelum dan sesudah dilakukan terapi kelompok pada pekerja seks komersial. Model terapi kelompok sangat diperlukan untuk mencegah penularan PMS pada kelompok beresiko.
\end{abstract}

Kata kunci: model terapi kelompok, perilaku seks, pekerja seks komersial

Abstract

The success of preventing sexually transmitted diseases (STDS) not only depends on a well-organised collaboration among government, health professionals and NGOs but also active participation of group with high risk, including commercial sex workers (CSWS), on the transfer of STDs. Involving this high risk group is crucial on preventing STDs transmission. Determining the effectiveness of Group Therapy Model (GTM) through an intensive problem solving group on promoting healthy sexual behavior was the intention of this study. The variables are knowledge, attitude and practice STDs. It is a pre-experimental study using Pretest-Post test type design. The samples involving 20 CSWs devided into two groups of 10 CSWs for each. Each group was intervened three times with GTM on the same subject. Statistical analysis using paired t-test, conclusion of accepting the research hypothesis. There is significant difference of knowledge, attitude and practices on STDs before and after the implementation of GTM among the CSWs. It is, therefore, adviced to consider GTM on preventing the transmission of STDs among high-risk groups.

Keywords: group therapy model, sexual behavior, commercial sex workers

\section{Pendahuluan}

Angka kejadian penyakit menular seksual (PMS) semakin mengalami peningkatan, salah satunya penyakit Acquired Immunodeficiency Syndrome (AIDS). Keberhasilan pencegahan penularan PSM tidak hanya bergantung pada pemerintah/tenaga kesehatan dan lembaga swadaya masyarakat (LSM) yang peduli dengan kasus ini saja, tetapi partisipasi aktif dari kelompok yang mempunyai resiko tinggi tertular (Pekerja Seks Komersial) sangat memegang peran penting untuk mengatasinya. Oleh karena itu mengikutsertakan kelompok resiko tinggi dalam kegiatan pencegahan PSM perlu untuk dilakukan.
Salah satu model untuk menyelesaikan permasalahan di atas adalah dengan mengefektifkan terapi kelompok. Terapi kelompok adalah metode untuk pengobatan dan penyelesaian masalah, yang berfokus pada peningkatan self awereness, hubungan interpersonal, penyesuaian sosial, kemampuan untuk menyelesaikan masalah, serta melakukan suatu perubahan (Beck, Rawlins, \& Williams, 1993). Dengan terapi kelompok maka individu akan belajar untuk mengemukakan pendapatnya, menghargai pendapat kelompok, memperoleh dukungan moral, dan memperoleh pengetahuan tentang permasalahan yang diajukan, sehingga diharapkan akan terjadi perubahan perilaku yang berdasarkan kesadaran diri sendiri. 
Model terapi kelompok yang akan dilakukan dalam penelitian ini adalah "model intensive problem solving groups", yaitu kelompok perlakukan akan diberi suatu permasalahan yang berkaitan dengan perilaku seks baik yang menyimpang maupun tidak menyimpang, dan kelompok akan mendiskusikan permasalahan tersebut serta mencari solusi/ penyelesaian masalah secara bersama sebagai upaya untuk meningkatkan derajat kesehatannya.

Penelitian iniperlu dilakukan untuk melihat sejauh mana efektifitas dari terapi kelompok pada pekerja seks komersial dalam meningkatkan perilaku seks yang sehat. Perilaku seks yang tidak sehat rawan untuk terjadinya penularan penyakit kelamin, dan kehamilan yang tidak diharapkan.

\section{Metode}

Desain penelitian ini adalah Pra-Eksperimen, dengan jenis pretest-postest design, dimana sudah dilakukan observasi pertama (pretes) yang memungkinkan peneliti dapat menguji perubahan-perubahan yang terjadi setelah adanya eksperimen. Terapi kelompok dilakukan sebanyak tiga kali dan setiap tahap dilakukan pengukuran, meliputi pengetahuan, sikap, dan kegiatan seks yang dilakukan. Bentuk rancangan penelitian sebagai berikut:

\begin{tabular}{|ccc|} 
Pre-tes & Perlakuan & Pos-tes \\
\hline 01 & $\mathrm{X}$ & 02 \\
\hline
\end{tabular}

Populasi penelitian ini adalah seluruh PSK di kawasan Bangunsari, dan kawasan Tambak Asri di kota Surabaya dengan jumlah sekitar 700 orang. Sampel penelitian kawasan Bangunsari satu kelompok, dan kawasan Tambak Asri satu kelompok, dengan jumlah masing-masing anggota kelompok sebanyak 10 orang, selanjutnya dibuat dua kelompok yaitu kelompok A yaitu responden berusia di bawah/sama dengan 20 tahun, dan group B responden berusia di atas 20 tahun.

Cara pengambilan data untuk mengukur pengetahuan responden dengan menggunakan kuesioner terbuka, untuk mengidentifikasi perilaku seks dengan wawancara mendalam, untuk mengukur sikap responden tentang perilaku yang sehat dengan menggunakan skala Likert, sedangkan untuk terapi kelompok model problem solving dengan menggunakan Focused Group Discussion (FGD) dengan bantuan panduan terapi kelompok. Guna melihat perbedaan sebelum dan sesudah dilakukan terapi kelompok digunakan uji statistik Paired T-test.

\section{Hasil}

Umur responden pada kelompok A yaitu kelompok pekerja seks dewasa muda, usia terkecil adalah 14 tahun $(20 \%)$, sedangkan pada kelompok B pekerja seks dewasa tua, usia tertua dalam kelompok adalah 51 tahun (10\%). Mayoritas responden berpendidikan tamat SD (90\%) baik dari kelompok A maupun kelompok B.

Dari hasil wawancara mendalam usia pertama kali melakukan hubungan seks pada kelompok A sebagian besar $(80 \%)$ pada usia $10-15$ tahun, sedangkan pada kelompok B sebagian besar melakukan hubungan seks pada usia 16 - 20 tahun (70\%). Penghasilan yang diperoleh PSK tiap Minggu pada kelompokA sebagian besar (70\%) lebih dari Rp300.000,- sedangkan penghasilan PSK kelompok B hampir separuh (40\%) mempunyai penghasilan kurang Rp100.000,-.

Hasil uji statistik Paired T-test dengan taraf significancy 0,05 diperoleh hasil terdapat perbedaan yang signifikan ( $p=0,000, \alpha=0,05)$ untuk pengetahuan dan sikap pada responden, sebelum dilakukan terapi kelompok dan sesudah dilakukan terapi kelompok baik pada kelompok A dan kelompok B (lihat pada tabel 1).

\section{Pembahasan}

\section{Pengetahuan responden}

Pengetahuan atau kognitif merupakan domain yang sangat penting untuk terbentuknya tindakan seseorang (over behavior). Seseorang bisa melakukan sesuatu yang salah karena mereka memang betul-betul tidak tahu, atau sebaliknya mereka mau melakukan hal yang salah tersebut dengan penuh kesadaran atau tahu betul tindakan yang dilakukan beserta segala resikonya. 
Solusi penyelesaian untuk dua permasalahan tersebut jelas berbeda, seseorang yang melakukan kesalahan karena tidak tahu, diharapkan setelah tahu secara pasti dia tidak berbuat kesalahan lagi, berbeda dengan orang yang tahu tetapi tetap berbuat kesalahan maka solusinya adalah perbaikan moral dan sikap.

Hasil penelitian awal tingkat pengetahuan responden, sebelum diberikan terapi kelompok (70\%) kelompok A memiliki pengetahuan yang kurang untuk kesehatan reproduksi dan penyakit-penyakit akibat hubungan seksual. Peneliti berasumsi pengetahuan yang kurang tersebut disebabkan minimnya informasi yang diterima baik dari segi kualitas maupun kuantitas. Dari wawancara pada beberapa responden mengatakan pernah diberi penyuluhan tentang penyakit AIDS atau PHS, tetapi mereka tidak paham betul, hal ini disebabkan karena penyuluhan tersebut bersifat general dan cenderung formal.

Menurut Rogers, sebelum seseorang mengadopsi perilaku baru di dalam diri orang tersebut terjadi proses yakni: awareness (kesadaran) di mana orang tersebut menyadari dalam arti mengetahui terlebih dahulu terhadap stimulus (objek), interest (merasa tertarik) terhadap stimulus atau objek tersebut, evaluation (menimbang-nimbang) terhadap baik dan tidaknya stimulus tersebut, trial (mencoba) di mana subyek mulai mencoba melakukan sesuai yang dikehendaki, adaption dimana subyek telah berperilaku baru sesuai pengetahuan, kesadaran, dan sikapnya (Notoatmojo, 1997).

Teori tersebut menyatakan bahwa untuk merubah perilaku seseorang tidaklah mudah, perlu pendekatan yang intensif dan pemberian informasi yang berulang sampai betul-betul seseorang paham dan tertarik terhadap stimulus tersebut. Dengan adanya diskusi kelompok ini maka masing-masing anggota kelompok dapat memperoleh informasi dan memberikan informasi lain sesuai dengan apa yang dibahas oleh kelompok. Semua anggota kelompok mempunyai peran yang sama dan semua dapat aktif terlibat dalam transfer informasi ini. Hal ini sesuai dengan pendapat Whyte (1956 dalam Niven, 1994) yang menyatakan keputusan yang diambil sekelompok orang lebih baik dibandingkan dengan keputusan individu. Karena keterbatasan penelitian, maka dalam penelitian ini semua teori Roger tidak dapat dievaluasi, khususnya tahap trial (mencoba), dan adaption. Hal ini disebabkan peneliti tidak dapat mengetahui atau mengamati secara langsung tentang perubahanperubahan tersebut, khususnya penggunaan kondom, apakah PSK benar-benar menggunakan atau tidak.

Setelah dilakukan terapi kelompok selama tiga kali terapi, tingkat pengetahuan responden mengalami perubahan. Hal ini diperkuat dari hasil uji statistik dengan menggunakan paired-t test, menunjukkan ada perbedaan yang sangat signifikan untuk tingkat pengetahuan sebelum dan sesudah dilakukan terapi kelompok, baik pada kelompok A (dewasa muda) maupun kelompok B (dewasa tua) $(p=0,000, \alpha=$ $0,05)$.

\section{Sikap Responden}

Beberapa ahli psikologi seperti Luis Thurstone, Rinses Liker, Charles Osgood, menyatakan bahwa sikap adalah suatu bentuk evaluasi atau reaksi perasaan yang mana dapat memihak (favorable) maupun yang tidak memihak (unfavorable) pada suatu obyek tertentu. Sesuatu yang telah diketahui atau diyakini individu dapat menjadi stereotype baginya sehingga pikiran dan sikapnya selalu terpola pada hal tersebut (Notoatmodjo, 1997).

Tabel 1. Perbedaan Pengetahuan dan Sikap Responden Sebelum dan Sesudah Dilakukan Terapi Kelompok

\begin{tabular}{|c|c|c|c|}
\hline Perbedaan Pengetahuan dan Sikap & $\begin{array}{c}\text { Pre-tes } \\
\text { Rata-rata }\end{array}$ & $\begin{array}{c}\text { Post-tes } \\
\text { Rata- rata }\end{array}$ & $\mathrm{p}$ \\
\hline 1. Pengetahuan kelompok A & 3.1000 & 8.4000 & 0.000 \\
\hline 2. Pengetahuan kelompok B & 4.8000 & 8.2000 & 0.000 \\
\hline 3. Sikap kelompok A & 2.5400 & 3.1100 & 0.000 \\
\hline 4. Sikap kelompok B & 2.4700 & 2.9400 & 0.003 \\
\hline
\end{tabular}


Hasil penelitian didapatkan (100\%) responden mempunyai sikap yang positif (favorable) terhadap perilaku seks yang sehat, hal ini menunjukkan bahwa mereka mempunyai keyakinan dan konsep yang baik terhadap perilaku seks yang sehat. Dari hasil analisis untuk sikap, seluruh responden menyatakan setuju dengan pernyataan hubungan seks yang sehat penting bagi kesehatan diri sendiri, dan mereka juga menyatakan tidak setuju jika pemakaian kondom adalah merugikan.

Di samping itu, hampir seluruh responden menyatakan mereka beresiko untuk terkena penyakit kelamin/ AIDS, dan tidak dapat menikmati hubungan seks yang dilakukan dengan pelanggan, dengan argumentasi bahwa mereka hanya bersifat melayani. Hubungan seksual atau yang disebut bersetubuh yang benar menurut etika, moral, dan agama adalah jika dilakukan melalui sebuah ikatan pernikahan antara seorang lakilaki dan perempuan yang dilandasi oleh rasa cinta, sehingga terjadi ikatan secara fisik dan emosional (Dianawati, 2002). Hal ini sesuai dengan teori bahwa sikap seseorang ditunjang oleh keyakinan dan konsep yang dimiliki.

Adanya sikap yang positif dari pekerja seks komersial terhadap perilaku seks yang sehat, diharapkan ada perubahan perilaku/ kesadaran untuk menggunakan kondom dan melakukan hubungan seks yang sehat. Setelah dilakukan terapi kelopok selama tiga kali, terlihat ada perbedaan sikap yang signifikan dibandingkan sebelum menjalani terapi kelompok, $(p=0,000, \alpha=0,05)$.

\section{Perilaku Seks Responden}

Faktor penentu atau determinan perilaku manusia sulit untuk dibatasi karena merupakan perpaduan dari berbagai faktor internal dan eksternal individu. Perilaku kesehatan adalah respon seseorang terhadap stimulus yang berkaitan dengan sakit, dan penyakit yang meliputi; health promotion behavior, health prevention behavior, health seeking behavior, and health rehabilitation behavior (Niven, 1994).

Hasil penelitian sebelum dilakukan terapi kelompok, diperoleh informasi mayoritas responden kelompok $\mathrm{A}$ (dewasa muda) dan kelompok B (dewasa tua) memiliki perilaku seks yang cenderung beresiko, dimana (70\%) responden kelompok Amengatakan memakai kondom saat hubungan seks apabila pelanggannya bersedia untuk memakai kondom, jika pelanggan tidak bersedia menggunakan kondom maka mereka akan tetap melakukan hubungan seks tanpa kondom.

Disamping itu, cara hubungan seks pada kelompok ini cenderung variatif yaitu dengan cara genitor-genital, oral, bahkan beberapa responden pernah melakukan hubungan seks lewat anus, seks rame-rame dengan lebih dari satu orang pelanggan dalam waktu yang bersamaan, dan juga menggunakan alat-alat berbahaya dalam melakukan hubungan seks, yang beresiko untuk mengalami injury atau trauma dari organ reproduksinya. Untuk melindungi diri dari penyakit kelamin sebagian besar responden mengkonsumsi obat-obat antibiotik tanpa resep dokter, misal supertetra, amoxcicylyn, dan amoxan. Penggunaan obat tersebut menurut beberapa responden atas saran teman, apabila salah satu mengeluh mempunyai gejalagejala penyakit kelamin, maka teman yang pernah menderita dan mengkonsumsi salah satu jenis obat tertentu akan menyarankan pada temannya. Hal ini sesuai dengan teoribahwa seseorang yang menderita penyakit kelamin akan datang ke tempat pelayanan kesehatan apabila yang bersangkutan sudah tidak mampu lagi untuk mengatasi permasalahannya, hal ini disebabkan karena stigma masyarakat tentang penyakit kelamin merupakan suatu hal yang memalukan.

Pada saat dilakukan terapi kelompok, responden diajak untuk saling berbagi pengalaman tentang perilaku seksnya, cara pencegahan yang dilakukan, dan tindakan yang dilakukan jika menderita penyakit kelamin, serta dengan memberikan materi pendidikan kesehatan khususnya kesehatan reproduksi dan PHS. Tampak respon positif dari responden untuk saling tukar menukar informasi, dan saling mendukung untuk memberikan solusi terhadap masalah-masalah yang kemungkinan timbul akibat dari pekerjaan yang dilakukan.

Fokus terapi kelompok ialah menjadi self awareness, peningkatan hubungan interpersonal, membuat perubahan atau ketiganya (Stuart \& Laraia, 2001). 
Hal ini terlihat pada waktu dilakukan terapi, responden berani mengemukakan pendapat karena mereka merasa senasib, mempunyai pengalaman yang tidak jauh berbeda, serta mempunyai keyakinan dan konsep yang sama tentang pekerjaan yang dilakukan.

\section{Hasil Focused Group Discussion ( FGD ) tentang Perilaku Seks yang Sehat}

Terapi kelompok yang digunakan dalam penelitian ini adalah intensive problem solving groups dengan menggunakan metode FGD. Dalam pelaksanaan terapi ini baik kelompok A maupun kelompok B dibantu 1 orang pemimpinFGD dan 1 orang notulen yang berasal dari tim peneliti sendiri. Pelaksanaan diawali dengan perkenalan masing-masing anggota kelompok, pada fase ini diharapkan ada hubungan saling percaya antara anggota kelompok, adanya keterbukaan dan rasa saling menghormati. Pada fase ini peneliti dapat melihat bagaimana karakter dari masing-masing anggota kelompok, ada anggota kelompok yang pemalu dan ada juga anggota kelompok yang memiliki rasa percaya diri cukup tinggi, seperti pernyataan berikut:

"Nama saya $N$, sorry....! Saya datang terlambat karena sibuk melayani tamu, maklum baru saja ada kapal yang mendarat".

Pernyataan di atas menunjukkan yang bersangkutan tidak malu mengakui diri sebagai seorang PSK, secara teori seseorang yang dapat menyadari "siapa saya?" adalah individu yang mempunyai konsep diri positif sesuai dengan teori Jauhary Window (Keliat, 2002). Di dalam teori ini dijelaskan bahwa individu harus tahu siapa dirinya dan orang luarpun tahu siapa dia, sehingga diharapkan pekerja seks komersial tahu secara pasti dan bertanggung jawab terhadap apa yang dilakukan baik dari segi kesehatan maupun moral, demikian juga dengan orang luar/pengguna jasa seks harus tahu akan resiko yang dapat ditimbulkan akibat hubungan seks bebas yang dilakukan. Pada saat diberikan permasalahan yang berkaitan dengan kondom, pada FGD yang pertama beberapa anggota kelompok mengatakan sebagai berikut:

"Saya mau pakai kondom sesuai dengan permintaan pelanggan, jika pelanggan mau ya...saya pakai, tetapi jika pelanggan tidak mau ya...saya tidak pakai”.
"Saya tidak mau pakai kondom, karena kata pelanggan saya...makan pisang kok sama kulitnya".

"Kalau tamu saya tidak mau pakai....ya....saya tidak pakai, eman-eman Rp.200.000,- masa hilang?"

Beberapa pernyataan di atas menunjukkan, mayoritas PSK akan memakai kondom jika pelanggan mau memakai. Hal ini dapat diasumsikan baik PSK maupun pelanggan PSK belum mempunyai ketetapan hati atau kesadaran untuk melindungi diri dari penularan penyakit kelamin dengan menggunakan kondom. Pada pelaksanaan terapi kelompok pertama, dibagikan 5 kondom gratis kepada peserta disertai beberapa leaflet yang terkait dengan kesehatan reproduksi dan penyakit AIDS. Respon daripeserta terhadap kondom tidak terlalu antusias, mereka menerima dengan sikap datar dan tidak terlalu peduli.

Pada pelaksanaan terapi kelompok yang ke dua diawali dengan pemberian pendidikan kesehatan tentang kesehatan reproduksi dan penyakit kelamin beserta pencegahannya. Dari hasil diskusi beberapa responden cukup aktif melontarkan beberapa pertanyaan dan beberapa anggota kelompok merespon dengan memberikan jawaban sesuai dengan pengalaman dan pengetahuan yang dimiliki masingmasing, seperti pertanyaan: "Bagaimana cara saudara mengetahui pelanggan yang mempunyai penyakit kelamin?’. Beberapa responden menjawab:

"Lampu terus menyala, sehingga saya tahu persis apakah pelanggan ada luka atau borok, jika ada boroknya saya yakin dia menderita penyakit kelamin".

"Saya pencet kemaluannya, jika ada nanah saya tidak mau melayani, karena pasti dia menderita penyakit kelamin".

"Saya bisa tahu dari bauya, jika pelanggan baunya tidak enak, kemungkinan besar dia menderita penyakit kelamin".

Jawaban responden tersebut dapat diasumsikan, beberapa responden sudah mengetahui secara praktis pelanggan yang menderita penyakit kelamin, dengan cara mendeteksi penyakit kelamin secara sederhana, hal ini dimungkinkan berdasarkan pengalaman atau informasi dari sesama PSK. 
Pada saat dilakukan diskusi kelompok ke dua, juga diberikan penyuluhan tentang cara menggunakan kondom secara benar, anggota kelompok dapat belajar dari sesama anggota lain, dan saling melengkapi sehingga pada akhir diskusi semua anggota kelompok mempunyai pengetahuan dan persepsi yang sama tentang masalah kesehatan yang sering dihadapi sehari-hari, khususnya yang berkaitan dengan penggunaan kondom.

Pada diskusi kelompok yang ke tiga, antara peneliti dan anggota kelompok sudah terjalin hubungan saling terbuka, masing-masing anggota kelompok sudah berani menceritakan permasalahan pribadinya tanpa malu-malu, dan mengharapkan ada masukan/ informasi dari anggota kelompok lain, seperti pertanyaan yang diajukan oleh salah satu anggota kelompok:

“....Pelanggan saya pernah memaksa saya untuk menggunakan alat-alat untuk berhubungan seks seperti cicin, gotri, bulu kambing yang dipasang pada kemaluan, apakah itu berbahaya untuk kesehatan saya?"

Pertanyaan diatas, menunjukkan anggota kelompok sudah mulai mencari informasi dan solusi yang berkaitan dengan kesehatannya, hal ini merupakan perkembangan yang sangat baik, karena individu sudah sadar tentang kondisi dan kemungkinan masalah yang timbul akibat perilaku seks yang dijalani. Beberapa jawaban dari anggota kelompok yang lain tentang permasalahan temannya, sudah sesuai dengan konsep kesehatan seperti pernyataan berikut:

“....Sebenarnya kita hanya digunakan sebagai alat pemuas pelanggan, dan itu sangat berbahaya, karena alat kelamin kita dapat rusak, kalau rusak kita tidak dapat mencari uang lagi, ruginya banyak sekali, kita dapat Rp. 200.000,- tapi jika sakit biayanya lebih dari itu."

"Kita harus berani menolak, jika tindakan tersebut sangat merugikan kita, pelanggan senang tetapi kita kesakitan?"

Jawaban tersebut mengambarkan adanya pemahaman yang sama tentang konsep perilaku seks yang membahayakan/merugikan, sehingga pada akhir diskusi sudah tercapai kesepakatan untuk berani menolak pelanggan jika perilaku seks tersebut merugikan kesehatan.

Pada akhir terapi kelompok perilaku responden terhadap penggunaan kondom sangat positif hal ini terlihat dari permintaan responden terhadap kondom.

"Bu.... Saya minta kondomnya lagi ya? Yang kemarin sudah habis".

"Saya masih aktif lho....minta kondomnya pak".

Pada pertemuan yang ketiga, dibagikan 10 kondom lagi secara gratis, tetapi beberapa PSK meminta lebih, dengan alasan pelanggannya cukup banyak dan akan berusaha untuk menggunakan kondom selalu.

Model terapi kelompok bertujuan untuk membantu anggota kelompok berhubungan dengan orang lain dan merubah perilaku yang maladaptive menjadi adaptive. Kekuatan kelompok ada pada konstribusi dari setiap anggota kelompok dalam mencapai tujuan kelompok.

Fungsi kelompok akan tercapai jika anggota kelompok berbagi pengalaman dan saling membantu satu sama lain. Dari hasil terapi kelompok yang dilakukan selama tiga kali pada PSK dapat dilihat banyak sekali perubahan yang bisa dilihat, baik pengetahuan, sikap maupun perilaku responden tentang seks yang sehat.

\section{Kesimpulan}

Terapi kelompok sangat efektif digunakan sebagai media pendidikan kesehatan, dengan terapi kelompok maka individu dapat mengembangkan diri secara positif, memperoleh pengetahuan secara aktif, serta dapat mengembangkan pola pikir realistis. Hal ini terbukti setelah dilakukan penelitian dengan menggunakan uji statistik paired t-test diperoleh hasil $p=0,000$ dan $\alpha=0,05$. Maka hipotesa penelitian diterima ada perbedaan pengetahuan, sikap dan perilaku sebelum dan sesudah dilakukan terapi kelompok pada pekerja seks komersial(NM, JS, YA). 


\section{Referensi}

Dianawati, A. (2002). Pendidikan seks untuk remaja (Cetakan ke 3). Jakarta: EGC.

Keliat, B. (2002). Konsep diri. Jakarta: EGC.

Niven, N. (1994). Health psychology: An introduction for nurses and other health care professionals. London: Churchill Livingstone.

Notoatmodjo, S. (1997). Ilmu kesehatan masyarakat. Jakarta: Rineka Cipta.
Rawlins, R.P., Williams, S.R., \& Beck, C.K. (1993). Mental health psychiatric a holistic hife-ycle approach. St. Louis: Mosby Year Book.

Stuart, G. W., \& Laraia, M.T. (2001). Principles and practice of psychiatric nursing. Seventh ed. Philadelphia. St Louis: Mosby Year Book.

Seseorang yang oprimis akan melihat adanya kesempatan dalam setiap malapetaka, sedangkan orang pesimis melihat malapetaka dalam setiap kesempatan.

- Anonim -

Orang besar bukan orang yang otaknya sempurna, tetapi orang yang mengambil sebaik-baiknya dari otak yang tidak sempurna.

- Anonim -

Ketahuilah bahwa sabar, jika dipandang dalam permasalahan seseorang adalah ibarat kepala dari suatu tubuh.

Jika kepalanya hilang maka keseluruhan tubuh itu akan membusuk. Sama halnya, jika kesabaran hilang, maka seluruh permasalahan akan rusak.

- Khalifah 'Ali -

Setiap hariberpotensi baik,

tetapi memang tidak setiap pribadi dari kita berfokus pada perasaan, pikiran, dan tindakan yang mengubah potensi baik menjadi kenyataan baik.

- Mario Teguh - 